\title{
VALTIONHALLINNON VIESTINTÄ SUOMESSA - BYROKRAATTISTA TIEDONSIIRTOA VAI JÄLKIBYROKRAATTISTA VIESTINTÄÄ?
}

\begin{abstract}
Artikkelissa pohditaan, miten viestinnän toimijat itse arvioivat organisaationsa viestintä̈n, ja millaisena he näkevät viestinnän roolin organisaatiossaan. Aineisto koostuu viidessä eri ministeriössä tehdyistä 16 tiedottajan ja neljän ministerin erityisavustajan haastatteluista. Haastattelut olivat osa Valtionhallinnon viestintä 2007 -hanketta. Tulokset osoittavat, että toimijat ovat kiinnostuneita ensisijaisesti tiedottamisen tehokkuuden mittaamisesta ja toisarvoisesti vuorovaikutteisen viestinnän toteutumisen arvioimisesta. Ulkoisesta viestinnästä ja arviointitarpeista kysyttäessä vastaukset kääntyvät systemaattisesti organisaation sisäisiin muutoksiin ja muutostarpeisiin. Toistuviksi teemoiksi nousevat viestintätoiminnan roolin muutos sekä kaivattu asennemuutos viestintätoimintaan omassa organisaatiossa. Tekstissä pohditaan, osoittavatko tulokset kä̈nnekohtaa byrokraattisesta tiedonsiirrosta jälkibyrokraattiseen viestintä̈̈n. Tuloksia tulkitaan sekä konstruktionistisesta että foucault'laisesta näkökulmasta.
\end{abstract}

Valtionhallinnon viestinnästä ja sen arvioinnista on tehty hätkähdyttävän vähän tutkimusta, vaikka se on yhteiskunnallisesti merkittävää (Hakala 2001, 4) ja kansalaisia varten (VNK 2002, 12; VNK 5/2001, 9). Artikkelissa tarkastellaan sitä, miten valtionhallinnon viestinnän toimijat arvioivat organisaationsa viestintää ja millaisena he näkevät viestinnän roolin organisaatiossaan. Tätä tulkitaan sekä konstruktionistisesta että foucault'laisesta näkökulmasta, jotta ymmärrettäisiin viestinnän ja viestinnän toimijoiden oma rooli viestintäkäytäntöjen tuottamisessa ja uudelleentuottamisessa. Valtionhallinnon viestinnän tarkastelu tällaisista teoreettisista lähtökohdista on tärkeää, jotta saataisiin ymmärtävää näkökulmaa valtionballinnon viestinnän tutkimukseen. Ymmärtävä näkökulma on puuttunut pitkään valtionhallinnon viestinnän ja sen arvioinnin tutkimuksesta (Hakala 2001, 5).

Foucault'lainen näkökulma tarjoaa kriittisyyttä valtakäytäntöihin, arviointikäytäntöjen ja viestinnän toimijoiden muokkauksen ymmärtämiseen (Townley 1994; 1998). Sosiaalinen konstruktionismi taas auttaa ymmärtämään organisaation arjen rakentumista ja uudelleenrakentumista sekä viestinnän toimijoiden aktiivista roolia tässä. Artikkelissa keskustellaan organisatorisen todellisuuden rakentumisesta, sosiaalisen konstruktionismin (Berger ja Luckmann

Tiedotustutkimus 2007:3 30:3, 19-32 
1966/1991) sekä Dian-Marie Hoskingin ja Ian Morleyn (1991) konstruktionistisen organisointiajattelun kautta. Lisäksi valtaa ja todellisuuden rakentumista tarkastellaan Michel Foucault'n tiedon ja vallan (1980) ja epistemen (1970; 1972) käsitteiden avulla.

Artikkelin empiirisenä aineistona käytetään Valtionhallinnon viestintä 2007 -hankkeessa (Nieminen ym. 2005a; 2005b) tehtyjä haastatteluita, joissa haastateltiin viestinnän toimijoita viidessä ministeriössä syksyllä 2004 (Huhtala 2005a; 2005b). Vaikka arviointikäytäntöjä on Suomessa tutkittu (esim. Lumijärvi ja Kaarlejärvi 2000), puuttuu valtionhallinnon viestinnän arviointikäytäntöjä selvittävä tutkimus Suomesta lähes täysin muutamia opinnäytetöitä lukuun ottamatta (Hakala 2005b, 137; Hakala 2006). Tästä syystä valtioneuvoston kanslia käynnisti Valtionhallinnon viestintä 2007 -hankkeen. Haastattelututkimuksen tutkimuskysymykset olivat (Nieminen ym. 2005a, 10)ः1) Mitkä ovat valtionhallinnon ulkoisen viestinnän yleiset arviointiperusteet?, 2) Mitkä ovat ministeriöiden hyvät käytännöt viestinnän toteutuksessa?, 3) Mitkä ovat viestinnän kehitystarpeet strategisen johdon ja toimijoiden mielestä? 4) Millaista tietoa näiden pohjaksi tulisi kerätä? Tässä artikkelissa tarkastellaan tutkimusaineistoa tutkimuskysymysten 1 ja 4 pohjalta.

Valtionhallinnon viestintä 2007 -hankkeen yhteiskuntateoreettisena viitekehyksenä käytettiin muun muassa John Deweyn (1927/2006) käsitystä julkisesta toiminnasta. Deweyn ajattelussa on keskeistä se, että ihmiset ovat olemassa vain subteessa toisiinsa ja maailmaan $(1927 / 2006$, 16). Deweyn ajatukset ovatkin lähellä tämän artikkelin konstruktionistista lähestymistapaa viestintään ja organisaation todellisuuteen. Deweyn mukaan sekä yksilöt että yhteisöt kehittävät tapoja ja tottumuksia, joiden avulla ne voivat selvitä ympäristöstään. Tavat, tottumukset ja muut kaavoittumat Dewey puolestaan näkee kulttuuriin kiteytyneenä tietona, jonka yhteisön jäsen oppii kasvaessaan. Kun rutiinit ja tavat eivät enää toimi, syntyy ongelmia. Ongelmista taas syntyy uutta tietoa, koska ongelmia kohdatessaan ihmiset ja yhteisöt joutuvat kehittämään ja kokeilemaan parempia toimintatapoja. Julkinen toiminta on aina tavalla tai toisella harkittua tai tiedostettua, koska "julkinen toiminta perustuu jostain yksityisestä toiminnasta aiheutuvien epäsuorien seurausten tiedostamiseen ongelmallisiksi ja niiden harkittuun sääntelyyn" (emt., 16-17).

Seuraavaksi esitellään artikkelin teoreettiset lähtökohdat, ja tarkastellaan viestintää byrokratiassa ja jälkibyrokratiassa. Tämän jälkeen käydään läpi näiden toimintatapojen rakentumista ja uudelleenrakentumista sosiaalisen konstruktionismin sekä Michel Foucault’n käsitteiden avulla. Tämän jälkeen esitellään menetelmä ja tulokset. Lopuksi tuloksista keskustellaan artikkelissa esitettyjen teorioiden kautta.

\section{VIESTINTÄ BYROKRATIASSA JA JÄLKIBYROKRATIASSA}

Gary Kreps $(1986,4)$ on tarkastellut organisaatioiden ja viestinnän suhdetta ja toteaa, että ihmiset täytyy suostutella toimimaan yhdessä, jotta yhteinen toiminta olisi mahdollistamista. Viestintä on suostuttelun keino ja sen perustehtävä on edesauttaa yhteistyötä. Organisaation tehtävä on puolestaan tehtävien koordinointi yhteisten tavoitteiden ja selviytymisen mahdollistamiseksi (Kreps 1986, 4). Viestinnän ymmärtäminen suostuttelun keinoksi, jonka perustehtävä 
on edesauttaa yhteistyötä, sopii hyvin yhteen sekä konstruktionistisen ajattelun että jälkibyrokraattisen organisaatiokäsityksen ja toimintatavan kanssa. Dialogi, neuvottelu ja vuorovaikutus korostuvat molemmissa. Charles Heckscherin (1994) mukaan byrokratiassa vaikuttaminen perustuu henkilön muodolliseen asemaan, kun taas jälkibyrokraattisessa organisaatiossa vaikutusvaltaa käytetään henkilökohtaisten ominaisuuksien ja suostuttelun avulla. Heckscher (1994, 25) onkin todennut: "Vuoropuhelu pohjautuu vaikutusvallan, ei niinkään vallan käyttöön. Toisin sanoen ihmiset vaikuttavat päätöksiin suostutellen, eivät käskien."

Byrokratiassa konsensus saavutetaan myöntyväisyydellä ja vallankäytöllä, kun taas jälkibyrokraattisessa organisaatiossa konsensus syntyy institutionaalisessa vuoropubelussa (Heckscher 1994, 25). Heckscherin mukaan byrokraattisessa organisaatiossa sisäisellä luottamuksella ei ole paljoakaan merkitystä, päätöksenteko on jäykkää, työntekijät pitävät yhtä ja organisaation rajat ovat tiukat ja läpäisemättömät. Jälkibyrokraattisessa organisaatiossa taas tarvitaan runsaasti sisäistä luottamusta, päätöksentekoprosessit ovat joustavia ja muuttuvia, sosiaalinen kanssakäyminen muodostuu erikoistuneiden funktionaalisten suhteiden verkostosta, ja organisaation rajat ovat avoimia ja helposti läpäistävissä (emt., 26-27). Jälkibyrokraattisessa organisaatiossa neuvottelu ja suostuttelu korostuvat. Näin niissä on Pekka Aulan kuvaamaa hajottavaa viestintää, joka on muun muassa proaktiivista ja dialogista (Aula 1999).

Eri organisaatiomuodot suosivat erilaista viestintää. Esimerkiksi byrokraattiseen toimintatapaan soveltuu yhdensuuntainen viestintä, vaikka toki byrokratioissakin on muita viestinnän tapoja, muun muassa neuvottelua ja dialogia. Jälkibyrokraattinen toimintamalli taas suosii neuvottelua, spontaania dialogia ja henkilökohtaista suostuttelua, vaikka jälkibyrokratioissakin on virallisia tapaamisia kuten byrokratioissa. Organisaatiokulttuuria, organisaatiomallia ja organisointia on tärkeää tarkastella myös viestinnän tutkimuksessa, koska ne luovat perustaa sille, miten organisaatiossa viestitään ja voidaan viestiä. Viestinnän käytännöt ja toimintatavat puolestaan vaikuttavat organisointiin ja organisaatioon.

Sekä John Deweya $(1927 / 2006,16)$ että sosiaalista konstruktionismia (Gervais 1999; Gergen 1999) soveltaen organisatorinen todellisuus ei ole ulkoisesti mä̈räytynyt, vaan rakentuu jatkuvasti ihmisten välisessä vuorovaikutuksessa sekä ibmisten ja kontekstin välisessä vuorovaikutuksessa. Valtionhallinnon byrokratia ja siihen liittyvä yksisuuntainen tiedottamistoiminta ovat ongelmallisia, koska organisaatio ja ympäristö hahmotetaan erillisinä yksikköinä, joita vaihtosuhteet yhdistävät. Organisaatio ja sen ulkopuoliset tahot ymmärretään erillisiksi kokonaisuuksiksi, jotka eivät ole keskenään suorassa vuorovaikutussuhteessa vaan vaihtosuhteessa. Byrokratian ongelmana on myös se, että rakenteet, ihmiset ja ihmisten väliset prosessit on erotettu toisistaan sen sijaan, että nähtäisiin yksilön ja organisaation suhde toisaalta yksilöiden välisenä ja toisaalta yksilön ja kontekstin välisenä vuorovaikutussuhteena (Humphreys, Berkeley $\&$ Jovchelovitch 1996). Tällainen näkökulma on sisäänrakennettu jälkibyrokraattiseen, toimijoita ja toimintaa rakenteiden sijaan korostavaan organisaatiomalliin. Myös viestintä, vuorovaikutus ja osallistaminen saavat enemmän tukea jälkibyrokraattisessa organisaatiomuodossa. Toki jälkibyrokratiassa on myös omat ongelmansa ja ongelmalliset muotonsa (Heckcher 1994, 28-45, 71-72; ks. myös Hodgson 2004). 
Viestintää voi tieteellisesti lähestyä kahdesta suunnasta: selittämisen tai ymmärtämisen näkökulmasta. Selittämisen näkökulmassa keskitytään muun muassa viestintäketjujen syntyyn, syy- ja seuraussuhteisiin ja tiedonkulun solmukohtiin (Huhtala ja Hakala, 2007, 30-31). Ymmärtämisen näkökulma paneutuu viestinnän tarkasteluun kulttuurisen kontekstin, yhteisyyden ja näiden rakentumisen kautta. Selittämisen näkökulmasta tarkastellaan sitä, kuka sanoo mitä, minkä kanavan välityksellä, kenelle ja millä vaikutuksella, kuten Harold Lasswell kehotti määritellessään viestinnän siirtomallia (Lasswell 1948).

Siirtomalli on jättänyt vahvan jäljen julkishallinnon viestintään, sillä byrokratiassa (Weber 1947; 1978) viestintä mielletään nimenomaan informaation siirtämiseksi viestinnän siirtomallin mukaisesti (Huhtala ja Hakala 2007, 93). Siirtomallissa viestinnän tehtävänä on pitää organisaatio koossa liiman tavoin - käytännössä usein vertikaalisessa suunnassa (emt., 31). Salli Hakalan (2001, 5) mukaan Suomessa keskustelu julkishallinnon viestinnästä kulttuurisen ybteisyyden rakentajana toteutui vasta vuosituhannen vaihteen tienoilla, kun kansainvälisessä viestinnän tutkimuksessa tämä lähestymistapa nousi siirtomallia suositummaksi jo useita vuosikymmeniä sitten. Gareth Morganin (1997) mukaan kulttuuri on yhteisen todellisuuden rakentamisen ja uudelleenrakentamisen tapa, jonka avulla ihmiset voivat ymmärtää yhteisellä tavalla tapahtumia, tekoja, objekteja, sanomisia ja tilanteita. Viestintä eri muodoissa on keskiössä tässä yhteisen todellisuuden rakentamisessa ja uudelleenrakentamisessa.

\section{SOSIAALINEN KONSTRUKTIONISMI, FOUCAULT JA ORGANISAATION RAKENTUMINEN}

Tunnetun konstruktionistin Kenneth Gergenin $(1999,60)$ mukaan sosiaalisessa konstruktionismissa päähuomio on diskurssissa itsen ja maailman artikuloinnin välineenä sekä tavassa, jolla tällainen diskurssi toimii sosiaalisissa suhteissa. Tieto syntyy pohjimmiltaan tietävän (subjekti) ja tiedetyn (objekti) suhteesta. Tässä prosessissa sekä tietävä että tiedetty muuttuvat. Ihmisten kokema todellisuus määritellään suhteessa toisiin (Gervais 1999, 1-3, ks. myös Gergen 1999). Sosiaalinen konstruktionismi on noussut myös organisaatiotutkimuksessa paljon käytetyksi teoreettiseksi viitekehykseksi (Huhtala 2006a). Kuten David Sims, Steve Fineman ja Yiannis Gabriel (1993) toteavat, organisaatioista puhutaan usein niin kuin ne olisivat pysyviä fyysisiä todellisuuksia. Organisaatiot koostuvat kuitenkin ihmisistä, jotka tekevät, ovat vuorovaikutuksessa toistensa kanssa, puhuvat, tapaavat, kirjoittavat, soittavat ja niin edespäin.

Yksinkertaisuudessaan sosiaalinen konstruktionismi ottaa organisaatioihin sovellettuna lähtökohdakseen sen, että ihmiset luovat rakenteita, suunnitelmia, tavoitteita, tuotteita, muutoksia, komiteoita, osastoja, statustasoja, lakkauttamissuunnitelmia ja loma-aikatauluja - eivätkä rakenteet, järjestelmät tai systeemit (Sims ym. 1993). Kaikki tämä toiminta viittaa sosiaalisesti rakentuneeseen maailmaan (Gergen 1999). Tästä näkökulmasta katsottuna organisoituminen on prosessien sarja ja jatkumo: organisaatio on jatkuva prosessi, jossa organisaation olemuksesta ja sen toiminnan organisoimisesta neuvotellaan jatkuvasti (Huhtala 2004). Tämä tapahtuu virallisesti ja epävirallisesti, tietoisesti ja tiedostamatta sekä verbaalisesti ja nonverbaalisesti. 
Peter Bergerin ja Thomas Luckmannin kirjaa The Social Construction of Reality; A Treatise in the Sociology of Knowledge voidaan pitää sosiaalisen konstruktionismin alkuteoksena. Sen keskeiset käsitteet ovat eksternalisaatio, objektivaatio ja internalisaatio, jotka esittävät miten asioista tulee ihmiselle tosia ja osa ihmisen sisäistä tietoisuutta (Berger ja Luckmann, 1966/1991, 149).

Dian-Marie Hosking ja Ian Morley $(1991,31)$ tutkivat konstruktionistisesta näkökulmasta ihmisten ja organisaatioiden keskinäisriippuvuutta organisaatiossa. Hoskingin ja Morleyn (1991) mukaan sosiaalinen järjestys rakentuu pohjimmiltaan vuorovaikutukselle. Ihmiset ovat vuorovaikutussuhteessa keskenään ja riippuvaisia toisistaan, koska tarvitsevat toistensa apua sosiaalisen järjestyksen ja todellisuuden rakentamisessa sekä omien tavoitteidensa saavuttamisessa. Neuvottelu on prosessi, jossa tämä tapahtuu.

Kirjoittajat keskittyvät kognitiivisiin, poliittisiin ja sosiaalisiin prosesseihin, joiden kautta organisaatiot heidän mukaansa syntyvät ja muuttuvat (1991, 67148; ks. myös Weick 1995). Hosking ja Morley näkevät ihmisen identiteetin kollektiivisena konstruktiona niissä sosiaalisissa prosesseissa, joihin ihminen jatkuvasti vaikuttaa. Tämän sosiaalisen järjestyksen kollektiivisen rakentumisen uskotaan tapahtuvan erilaisten kognitiivisten, poliittisten ja sosiaalisten organisointiprosessien kautta, jotka tapahtuvat sekä yksilö- että kollektiivitasolla. Nämä organisointiprosessit ovat myös luonteeltaan symbolisia, ja periaatteessa ne mahdollistavat yhteistoiminnan. Kognitiiviset, poliittiset ja sosiaaliset organisointiprosessit ovat keinoja luoda, ylläpitää ja muuttaa organisaatioita ja sosiaalista järjestystä (Hosking ja Morley 1991, 74-81; ks. myös Hosking ja McNamee 2006). Tässä tulkinnassa viestinnän toimijoiden oma toiminta ja asenne ja niiden muutos vaikuttavat paitsi heidän omaan toimintaansa, myös organisaation muiden jäsenten käsitykseen viestinnästä ja viestintäyksikön toiminnasta. Käsityksiä muutetaan toimijoiden vaikutusvallalla, joka on kuitenkin kontekstisidonnaista ja vaihtelee toimijoittain.

Ongelmallista Hoskingin ja Morleyn ajatuksissa on se, että he tarkastelevat valtaa etupäässä vaikutusvaltana toisiin (influence) $(1991,134)$. Valta rinnastettuna vaikutusvaltaan nähdään ikään kuin yksilön ominaisuutena (1991, 124-135). Foucault'laisen analyysin mukaan myös organisaatiotutkimuksessa on esitetty (esim. Deetz 1992), että valta ei ole rakenne eikä ihmisen ominaisuus tai omaisuutta, vaan kaikkialla läsnä oleva tuottava voima (Alvesson ja Willmott 1992; Alvesson ja Deetz 2000; Rose 1999; Deetz 1998; Townley 1998). Foucault'n valtakäsityksessä valta, subjektiivisuus ja tieto (totuus) kytkeytyvät luonnostaan toisiinsa (Foucault 1980, 78-109). Tämän takia poliittisia prosesseja työpaikoilla, kotona ja yhteiskunnassa ei pidä nähdä vain sosiaalisesta järjestyksestä neuvottelemisena, jossa eri ihmiset kilpailevat ja toimivat omine tavoitteineen ja etuineen. Sen sijaan kaikkialla läsnä olevat valtasuhteet vaikuttavat osallistujiin ja muuttavat heitä. Samalla valta, joka toimii sekä subjektia muokaten että sen kautta, ohjaa heidän toimintaansa (Foucault 1977; 1981; 1997). Siksi subjektiviteetti vaikuttaa myös organisaatiotodellisuuden päivittäisessä rakentumisessa ja uudelleenrakentumisessa, oli organisaation tapa toimia sitten byrokraattinen, jälkibyrokraattinen tai jokin muu.

Foucault'n ajattelussa tieto ja valta ovat lähtökohtaisesti kietoutuneet toisiinsa (Foucault 1980,79-108). Valta tuottaa tietoa: kaikki tieto tuottaa valtasuhteita, ja kaikki valtasuhteet tuottavat tietoa (Foucault 1977, 27). Vallan mekanismit ovat samalla tiedon muodostamisen ja hankkimisen mekanismeja (Townley 
1998). Valta ja tieto toimivat diskurssien kautta. Valtasuhteita "ei voi itsessään muodostaa, vahvistaa eikä toteuttaa ilman diskurssin tuottamista, kertymistä, kierrättämistä ja toimintaa. Ei voi olla vallankäyttöä ilman eräänlaista totuuden diskurssien talouselämää, joka toimii tämän keskinäisen suhteen kautta ja sen ehdoilla” (Foucault 1980, 92-108). Valtaa ylläpidetään ja tuotetaan lukuisin hienovaraisin tavoin, esimerkkinä diskursiiviset käytännöt, joilla rajoitetaan, mitä voi ja mitä ei voi sanoa, tehdä tai ajatella.

Pidemmälle vietyinä Foucault'n totuuden diskursseilla (discourses of truth) määritellään, mikä on normaalia ja mikä ei, mitä yksilöt voivat tehdä, ajatella, sanoa ja olla erilaisissa tilanteissa ja mitä eivät. Niillä määritellään esimerkiksi se, millaista on "normaali" viestintä ja tiedottajan työ sekä mikä viestinnän roolin ylipäätään "kuuluu” ministeriöissä olla. Foucault'laisesta näkökulmasta totuuden diskursseilla määritellään muun muassa se, onko viestinnällä roolia eri tilanteissa ja mikä tämä rooli on. Totuuden diskurssit tunnistaa siitä, että niitä pidetään arjessa yleensä itsestäänselvyyksinä. Tästä syystä niitä ei kyseenalaisteta vaan huomaamattaan meistä itse kukin omassa arjessaan uudelleen tuottaa niitä. Tiedottajatkaan eivät siis välttämättä ehdi kyseenalaistaa, miksi he ovat mukana vain tietyissä palavereissa tai miksi heidän toimintaansa ei juuri ole arvioitu - toisin kuin ministeriöiden monia muita toimintoja.

Totuuden diskurssit ovat (väite)diskursseja, jotka sijoittavat yksilöt eettiseen tai moraaliseen kehykseen (Foucault 1981). Työpaikkakontekstissa totuuden diskurssit määrittävät vallitsevan totuuden erilaisista asioista, kuten työoloista, työtavoista ja asenteista, ja pyrkivät lisäksi tulkitsemaan totuuden subjekteja (subject of truth). Asiantuntijoiden, instituutioiden ja tekniikoiden välityksellä organisaation totuuden diskursseilla määritellään, luokitellaan ja tyypitellään se, mitä organisaatiossa pidetään normaalina ja asianmukaisena työn subjektina erilaisissa organisaatioympäristöissä tiettynä historiallisena ajankohtana (Rose 1999). Toisin sanoen, millainen on muun muassa "normaali" tiedottaja, hänen toimenkuvansa ja toimintatapansa byrokratiassa ja jälkibyrokratiassa.

Foucault kuvailee kirjoituksissaan, kuinka diskurssit alkavat käyttää subjektia tiedon objektina ja samalla, soveltaessaan tätä tietoa itseensä, subjekteista tulee oman itsensä objekteja. He alkavat muuttaa, muokata ja sopeuttaa itseään totuutena pitämäänsä tietoon - niistä tulee siis totuuden subjekteja. Tämän voi ajatella kuvaavan myös sitä, miten viestinnän toimijat saavat muun muassa oman käsityksensä siitä, millainen on normaali valtionhallinnon viestijä. Miten hänen odotetaan toimivan toisaalta oman organisaationsa sisällä tai miten kansalaiset odottavat hänen toimivan? Pidetäänkö häntä organisaatiossa "normaalina” viestinnän toimijana silloin, kun hän keskittyy tiedottamiseen vai kun hän keskittyy kansalaisten osallistumiseen viestinnän keinoin?

Foucault'n episteme-käsite puolestaan kuvaa tiedon muodostumista tiettyjen perusoletusten varaan, jotka ovat niin itsestään selviä epistemeä eläville ihmisille, että he eivät niitä havaitse (Foucault 1970). Epistemejä voi myös olla useita yhtä aikaa ja ne voivat olla vuorovaikutuksessa keskenään, mutta eri tieto- tai valta-systeemien osia. Episteme määrittää tietoa ja sen diskursseja, jotka ovat kullakin ajanjaksolla mahdollisia (Foucault 1970; 1972). Organisaatiotasolla se voidaan näbdä kulloinkin hallitsevana käsityksenä organisaation todellisuudesta. Episteme-käsitettä käyttäen on mielenkiintoista tarkastella toisaalta valtionhallinnon viestinnän episteemisten ajattelu- ja toimintamallien ilmenemistä, ja toisaalta pohtia enteilevätkö artikkelin empiiriset tulokset murrosta episteemissä. 


\section{TUTKIMUSAINEISTO JA -MENETELMÄ}

Haastattelututkimus suoritettiin lokakuussa 2004. Tutkimus oli laadullinen, ja tutkimusmetodina käytettiin puolistrukturoituja haastatteluita. Etnografia olisi tarjonnut haastatteluita hedelmällisemmän lähestymistavan ministeriöiden viestinnällisen toiminnan ja tekemisen tarkasteluun arjessa (Delamont 2004), mutta etnografia ei ollut käytännöllinen vaihtoehto menetelmäksi, koska kyseessä oli tilaustutkimus. Puolistrukturoiduilla yksilöhaastatteluilla pystyttiin hakemaan vastauksia tutkimuskysymyksistä johdettuihin haastattelukysymyksiin, mutta toisaalta jättämään tilaa haastateltaville vastata laajasti ja kertoa asioita kysymysten ulkopuolelta (Flick 1998, 130-131). Tapaustutkimus sopi tutkimusasetelmaksi, koska Valtionhallinnon viestintä -hankkeessa käytettiin useita menetelmiä, ja tapaustutkimus mahdollistaa monien menetelmien yhdistämisen hyvin (Denzin ja Lincoln 2000, 435; Yin 1994). Tutkimusasetelma mahdollisti myös ilmiön tutkimisen tilanteessa, jossa ilmiön (viestintä ja viestinnän arviointi) rajoja ei voida selkeästi erottaa kontekstista.

Haastatteluissa kysyttiin muun muassa tällä hetkellä käytössä olevista arviointimittareista, haastateltavan sekä viestintäyksikön tiedontarpeista suhteessa viestinnän arviointiin, viestinnän ja arvioinnin pääkehitystarpeista ja hyvistä käytännöistä (Nieminen ym. 2005b, 171-176). Tutkimusaineisto muodostui 20 toimijan haastattelusta, joista 16 oli tiedottajia ja 4 erityisavustajia. Haastateltavat valittiin viidestä ministeriöstä, jotka olivat kauppa- ja teollisuusministeriö, työministeriö, valtioneuvoston kanslia, valtiovarainministeriö ja ympäristöministeriö. Valinnat tehtiin tehtävänimikkeen ja työnkuvan mukaan eri viestinnän funktioista, ja haastateltavat jakautuivat seuraavasti: neljä ministerien erityisavustajaa, viisi viestintäpäällikköä, kaksi verkkotiedottajaa, kaksi substanssiasiantuntijaa, kaksi päätöstiedottajaa, kaksi sektoriyhteistyövastaavaa, yksi sisäisen viestinnän asiantuntija ja kaksi mediasuhteiden hoitajaa. Jokainen haastattelu kesti noin 1 1/2 tuntia. Haastattelut suoritettiin haastateltavien työpaikoilla virka-aikana. Kaikki haastattelut nauhoitettiin ja litteroitiin. Haastattelut ovat luottamuksellisia.

Haastattelujen analysoinnissa käytettiin temaattista analyysiä. Temaattinen analyysi tehtiin suhteessa tutkimuskysymyksiin. Ne muodostivat analyysin pääkategoriat, jotka ovat arviointiperusteet, viestinnän tieto- ja kehittämistarpeet ja hyvät käytännöt. Näiden kategorioiden sisällä teemoja tarkasteltiin määrällisesti ja tuloksiin nostettiin ne teemat, joista eri toimijat puhuivat määrällisesti eniten. Nämä teemat ovat tekstissä kursivoituna. Lisäksi analysoitiin tutkimuskysymyksiin pohjaavat teemat, jotka leikkasivat analyysin pääkategorioiden läpi. Artikkelia varten analysoitiin uudelleen haastatteluista nämä läpileikkaavat teemat ja haastatteluosiot, joissa kysymykset koskivat viestinnän onnistumisen ja epäonnistumisen arviointia, sisäistä viestintää, viestijöiden tiedontarpeita ja viestinnän kehitystarpeita. Erityisavustajien haastattelulomake oli hieman erilainen, ja siitä analysoitiin tätä artikkelia varten uudelleen kysymyskokonaisuudet, jotka liittyivät arviointiin ja yhteistyöhön.

Seuraavassa esitän aineiston uudelleenanalysoinnin keskeisimmät tulokset. Haastattelulainauksen jälkeen on merkitty, oliko haastateltava erityisavustaja vai tiedottaja ja haastattelun numero. Suorien haastattelulainausten kieltä on huollettu. 


\section{VIESTINNÄN ARVIOINTI JA ARVIOINTITARPEET}

Keskeiseksi teemaksi viestinnän arvioinnissa nousee viestinnän ymmärrettävyys ja ymmärrettävyyden arviointi. Haastatteluissa todetaan kerta toisensa jälkeen, että kansalaisille on viestittävä ymmärrettävällä kielellä, ja että tämän toteutumista tulisi arvioida:

...et ehkä just enemmän tätä seurantaa, miten viesti menee läpi ja miten se ymmärretään... Ehkä enemmän tällaista seurantaa, vaikka vaan et kun tiedote lähtee, miten se on otettu vastaan ja onko se kansalainen ymmärtänyt sen, mitä tässä nyt muuttuu. (Tiedottaja, haastattelu 1)

Toisena keskeisenä teemana korostetaan viestien perillemenoa ja sen mittaamista. Tässä yhteydessä korostetaan myös oman näkökulman välittymistä halutulla tavalla, ja mainitaan toistuvasti, että viestin välittymistä perille edesauttavat ymmärrettävän kielen lisäksi asioiden ilmaiseminen yleistä kiinnostusta ja median kiinnostusta herättävällä tavalla.

Tietenkin se, että ensin pääsee läpi tiedotusvälineistä ja sitten vielä se, että olisi tullut siteerattua oikein tai se meidän näkökulma tuotu esiin. (Tiedottaja, haastattelu 4)

Lisäksi todetaan, että viestien ymmärrettävyyden tärkeyttä ei oikein vielä ymmärretä organisaation sisällä, viestinnän osaston ulkopuolella, vaan usein käytetään hankalaa kieltä, kuten erikoisterminologiaa. Vastaavasti tiedottajien roolia viestinnän ymmärrettäväksi tekemisessä korostetaan.

Mä puhun nyt enemmän näistä muista kuin tiedottajista, nämä virkamiehet pitää saada ymmärtämään, että tämä viestintä on demokratian toteutumisen kannalta tärkeää toimintaa. Ja viestintään kohdistuu yhä suurempia paineita kaikkien evaluointien ja arviointien perusteella, niin kansalaiset vaan odottaa enemmän tältä tiedonsaannilta. (Tiedottaja, haastattelu 7)

Näiden kahden teeman lisäksi analyysissä nousee esiin vahvasti henkilöverkostojen sekä ylipäätään sisäisten ja ulkoisten verkostojen ja ybteistyön tärkeys. Sisäisesti yhteistyötä virkamiesten kanssa pidetään ensiarvoisen tärkeänä ja siitä toivotaan tiiviimpää siten, että viestinnän osaston mukaan ottaminen asioista tiedottamiseen olisi vuorovaikutteisempi prosessi. Tiedottajan tulisi päästä mukaan asiasta tiedottamisen suunnitteluun jo nykyistä paljon aikaisemmassa vaiheessa - jotta viestit olisivat ymmärrettäviä ja menisivät mahdollisimman hyvin perille. Muutama haastatelluista on kiinnostunut myös tiedottajien vastuunjaosta niin, että jokaisella tiedottajalla olisi tietty osasto ministeriössä, jonka viestintään tiedottaja on erikoistunut. Tämä lisäisi tiedottajien tietämystä asiasisällöistä ja edesauttaisi niistä kertomista ymmärrettävämmin kansalaisille. Haastatteluissa korostuu siirtyminen enemmän asioiden tiedottamisesta asioiden valmisteluun sekä sisäisen että ulkoisen yhteistyön avulla. Sisäisessä yhteistyössä toivotaan entistä enemmän yhteistyötä virkamiesten kanssa prosessien 
aikaisemmassa vaiheessa. Ulkoiseen yhteistyöhön liittyen toivotaan, että erilaisen sisäisen yhteistyön tuloksena voitaisiin kansalaisille viestiä aiemmin.

Mutta täälläkin on semmoinen rakenteellinen kehitystarve niin kun sanotaan yhteistoiminta viestinnän ja sitten näitten toimijoiden, esittelijöiden, miten se nyt halutaan sanoa, niiden välillä... siinä on vielä paljon parannettavaa. Se on kehityskohde numero yksi. (Tiedottaja, haastattelu 6)

Henkilökohtaisten verkostojen tärkeyttä alleviivataan, erityisesti suhteessa toimittajiin, viranomaisiin, omaan hallinnonalaan, omaan ammattikuntaan ja muihin sidosryhmiin. Näitä verkostoja ja mahdollisuutta verkostoitua kaivataan lisää. Konkreettisesti tähän tarvitaan haastattelujen mukaan lisää aikaa ja taloudellisia resursseja. Sidosryhmät, yhteistyötahot ja verkostot mainitaan myös tahoiksi, jotka tulee ottaa huomioon viestinnän arvioinnissa.

...niin kun kokonaisuutena huomioida ja selvittää ja käydä läpi meidän medioiden kontaktit ja mediasuhteiden hoitoa eli että miten me voitaisiin päästä henkilökohtaisempaan kontaktiin ja suhteisiin median kanssa että toki meitä sitoo se, että valtiontahon edustajana kaikille pitää kertoa yhtä aikaa yhtä paljon ja tämmöinen hyvin demokratisoiva meininki, mutta kuitenkin mediat on yksilöitä ja ne käy kilpailua keskenään ja henkilökohtaisista toimittajakontakteista on hyötyä, miten me tämä mediasuhteiden vaikuttavuus voitaisiin hyödyntää täysmääräisesti... (Tiedottaja, haastattelu 8)

Haastatteluaineistosta nousee selvästi esiin, että tällä hetkellä viestinnän arviointi perustuu kunkin toimijan omaan arvioon.

Eihän meillä ole mitään tämmöistä niin kun mittareita, millä sitä arvioitaisiin, että sehän on tämmöistä mutu-arviointia. (Erityisavustaja, haastattelu 1)

Arviointijärjestelmää ja -mittareita kaivataan arjen toiminnan tueksi. Systemaattista analyysia oman työn sekä yksikön työn tueksi kaivataan muun muassa mediaseurannasta, verkossa kävijöistä, sidosryhmistä ja palautteesta. Lisäksi arvioinnin avulla toivotaan viestinnän tuloksista ja merkityksestä konkreettista tietoa - ja näyttöä - myös muualle organisaatioon. Viestinnän merkitystä täytyy perustella, ja mittarit ja tulokset viestinnän "tehokkuudesta" ja toimivuudesta auttavat haastateltavien mukaan luonnollisesti tässä. Ensisijaisesti mittareita ja arviointia halutaan kuitenkin oman työn tueksi.

Kaiken kaikkiaan, tuloksista heijastuu ensisijaisesti tarve mitata oman, eri kanavilla lähetetyn sanoman perillemenoa kansalaisten keskuudessa. Tämä kertoo, että vallalla oleva, episteeminen, ajattelutapa viestinnästä on yksisuuntainen tiedottaminen, jossa viranomainen tarkastelee ensisijaisesti oman sanomansa läpimenoa. Valtionhallinnon viestintäsuositus erottaa tiedottamisen ja viestinnän (VNK 2002). Tiedottamisella tarkoitetaan organisaation omasta 
aloitteesta tapahtuvaa tiedon välittämistä, esimerkiksi tiedottamista joukkoviestimille. Viestintä puolestaan kattaa kaikki erilaiset tilanteet ja toiminnot, joissa viranomaiset vastaanottavat, tuottavat ja jakavat informaatiota, osallistuvat julkiseen keskusteluun ja luovat kansalaisten kanssa vuorovaikutuksessa merkityksiä yhteiskunnallisista asioista (VNK 2002; VNK 5/2001).

Vallalla oleva viestintätapa heijastaa myös organisaation sisäistä hallintokulttuuria ulospäin (Hakala 2001, 5). Tästä syystä onkin mielenkiintoista kysyä, mitä yksisuuntaisen tiedottamisen korostaminen kertoo viranomaisen hallintokulttuurista ja organisointitavasta? Byrokratiassa viestintä mielletään usein yksisuuntaisen informaation välittämiseksi, tiedottamiseksi (Huhtala ja Hakala, 2007). Jälkibyrokraattisessa organisaatiossa viestintä sitä vastoin mielletään enemmän vuorovaikutteiseksi prosessiksi, viestinnäksi (Huhtala 2006b). Tulokset antavat syytä olettaa yksisuuntaisen tiedottamisen ja siihen liittyvän byrokraattisen toimintatavan vallitsevan tutkituissa organisaatioissa.

\section{VIESTINNÄN ROOLIN MUUTOS JA ASENNEMUUTOS}

Laajin läpileikkaava teema aineistossa on viestinnän rooli ja sen muutos. Haastateltavat kertovat asioiden ennakoinnin tärkeydestä reagoinnin sijaan ja korostavat viestinnän aktiivisuutta ja proaktiivisuutta. Todeten samalla selväsanaisesti, että tämä on uutta, ja tässä organisaation ja heidän pitäisi kehittyä.

Hm... viestintään ylipäätään on kiinnitetty... paljon enemmän huomiota on tämän talon sisällä selvästikin se näkyy joka paikassa sekä ylin johto ja meidän osastot ja kaikki ja sitten on tietysti tullut... tietysti nämä tämmöiset erilaiset... nämä et kansalaisten pitäisi päästä vaikuttamaan enemmän asioihin niin sitä kautta myös on tietysti alettu enemmän kiinnittää näihin huomiota myöskin joo. (Tiedottaja, haastattelu 2)

Toisena läpileikkaavana teemana nousee se, että viestintään subtautumiseen kaivataan asennemuutosta. Toivotaan, että viestinnän merkitys tiedostetaan erityisesti organisaation sisällä. Tässä on havaittu paljon muutosta viime vuosina, mikä liittyy osaltaan myös viestinnän kasvaneeseen toimintakenttään, kuten sidosryhmäviestintään, verkkoviestintään sekä viestinnän tärkeyteen siviilikriisitilanteiden hoidossa (Huhtala, Hakala, Laakso \& Falk 2005).

No se proaktiivisuus on semmoinen käsite, joka on hyvin haasteellinen hallinnossa, että miten voitas päätöksistä ja asioista jo ennakoivasti kertoa yleisölle ja asiakkaille. Mutta tuota se, se ei ole mitenkään helppoa, sillä hallinnossa on virkamiehillä kuitenkin vanhastaan tätä asennetta, että keskeneräisistä asioista ei saa kertoa, vaikkakin nyt uusi julkisuuslaki antaa siihen mahdollisuuden. Mutta se on semmoinen josta puhutaan, mutta se ei kyllä hirveän paljon vielä toteudu. Mutta sekin on hyvä että siitä puhutaan... ( Tiedottaja, haastattelu 8) 
On mielenkiintoista huomata, että vaikka tutkimuksessa kysyttiin nimenomaan ulkoisesta viestinnästä ja sen arviointiperusteista, vastauksissa nousee esiin erityisesti sisäisen viestinnän ongelmia ja onnistumisia. Suurimpana teemana erottuu viestinnän roolin muutos organisaation sisällä. Kuten jokunen haastateltu osuvasti toteaa, ulkoista viestintää ja sisäistä toimintaa on vaikea erottaa toisistaan. Viestinnän rooli on haastateltujen mukaan nyt aktiivisempi ja keskeisempi kuin aiemmin, jolloin viestintä nähtiin lähinnä muiden toimintaa tukevaksi toiminnoksi. Viestinnän toimijat kokevat myös oman roolinsa muuttuneen aktiivisemmaksi verrattuna aiempaan.

Tätä viestinnän aktiivisempaa roolia voisi tulkita sosiaalisen konstruktionismin teorian (Berger ja Luckmann 1966/1991, 149-193) mukaan muun muassa siten, että viestinnän toimijat ovat käynnistäneet pohdinnan viestinnän aiempaa aktiivisemmasta roolista ministeriössä (eksternalisaatio). Ajatusta aktiivisesta roolista ovat toistaneet viestinnän toimijat ja joissain organisaatioissa myös johto. Vähitellen se on muuttunut normaaliksi asiaksi viestinnän toimijoiden keskuudessa (objektivoituminen). Yhteys idean esittämiseen ja sen sosiaaliseen alkuperään (viestinnän toimijoihin ja osin organisaation johtoon) ei kuitenkaan ole täysin hävinnyt, vaan idea on tullut todeksi lähinnä näiden tahojen toiminnalla - ja ehkä myös näiden tahojen keskuudessa. Viestinnän toimijat ovat sisäistämässä omaa rooliaan aktiivisina viestijöinä, joilla on tärkeä, jopa strateginen tehtävä (internalisaatio). Kun viestinnän toimijat ovat vuorovaikutuksessa organisaation muiden jäsenten kanssa, he heijastavat muutosta omalla muuttuneella toiminnallaan organisaatioon.

Toimijat ovat siis aktiivisia itsensä, työnsä ja organisaationsa muokkaamisessa (Arendt 1958/2002). Toimijat ovat myös vuorovaikutuksellisia organismeja (Dewey 1927/2006). Herää kysymys, enteileekö tämä viestinnän toimijoiden muutos aktiivisemmiksi subjekteiksi episteemistä murrosta viestinnän toimijoiden ja viestinnän osaston roolista valtionhallinnossa? Tai voivatko muutokset osoittaa siirtymistä byrokraattisesta tiedottamisesta jälkibyrokraattiseen viestintään?

Tulokset kertovat yksiselitteisesti, että viestinnän toimijoiden ja viestinnän osastojen tehtävä on edelleen ensisijaisesti tiedottaa. Tiedottamisen korostaminen kertoo, että se on edelleen vallitseva todellisuus, episteemi, valtionhallinnossa. Mielenkiintoista on, että itse toiminta eli tiedottaminen on pysynyt suhteellisen samana, mutta sekä tiedottajien että viestintäosaston rooli on muuttunut organisaatioiden sisällä. Näyttää, että byrokratia on nostanut viestintää ja sen toimijoita aiempaa strategisempaan asemaan organisaation sisällä, mutta sisällöllisesti se, mitä toimijat tekevät ei ole muuttunut paljoakaan - viestintä on edelleen pääsääntöisesti tiedottamista. Tämän aineiston perusteella byrokraattinen tapa toimia on yhä vallitseva episteemi valtionhallinnossa, jota viestinnän toimijat myös itse uusintavat. Aktiivinen toimijuus, joka yleensä sisältyy jälkibyrokraattiseen toimintatapaan, on saatu hallinnoitua vallitsevaan byrokraattiseen episteemiin.

Tämä tutkimus tehtiin syksyllä 2004. Tämän jälkeen viestinnän tärkeyttä on korostettu niin ministeriöiden johdon puheissa, mediassa kuin akateemisessa maailmassakin, erityisesti siviilikriisien hoidon yhteydessä (Huhtala ym. 2005a; Huhtala 2006; Huhtala ja Hakala 2007). Nyt, kolme vuotta myöhemmin olisikin mielenkiintoista haastatella samoja toimijoita uudelleen viestinnän mahdollisesta episteemisestä muutoksesta kohti vuorovaikutteista ja osallista- 
vaa viestintää. Viestinnän mahdollista muutosta on mielenkiintoista tarkastella mahdollisena indikaattorina pyrkimyksestä episteemiseen muutokseen organisointitavassa ja -kulttuurissa. Mikäli viestinnän roolin, aseman ja käytäntöjen muutos on suuri kohti ymmärtävää vuorovaikutteista viestintää, tämä voisi heijastaa siirtymää byrokraattisesta organisointitavasta kohti jälkibyrokratiaa. Tämä tarkoittaisi siirtymää pois byrokraattisen organisaation käsityksestä, jossa rakenteet erotetaan selkeästi ihmisistä ja heidän välisistä prosesseista (Humphreys ym. 1996), kohti jälkibyrokraattista käsitystä organisaatiosta, jossa toimijuus on keskiössä rakenteiden sijaan. Lopuksi viestinnän tutkimuksen näkökulmasta voisi kysyä, miten jälkibyrokraattinen organisaatio ja ymmärtävän viestinnän tutkimuksen tarve kulkevat käsi kädessä.

Kirjoittaja kiittää Emil Aaltosen säätiötä ja Suomen Akatemiaa (päätös numero 108618) artikkelin kirjoittamisen mahdollistamasta rahoituksesta sekä kahta anonyymia arvioitsijaa hyödyllisistä kommenteista.

\section{Kirjallisuus}

Alvesson, Mats \& Hugh Willmott (toim.) (1992) Critical Management Studies. London: Sage Publications.

Alvesson, Mats \& Stanley Deetz (2000) Doing Critical Management Research. London: Sage Publications.

Arendt, Hannah ([1958] 2002) Vita activa. Ihmisenä olemisen ehdot. Tampere: Vastapaino. (Englanninkielinen alkuteos The Human Condition, 1958.)

Aula, Pekka (1999) Organisaation kaaos vai kaaoksen organisaatio? Dynaamisen organisaatioviestinnän teoria. Helsinki: Loki-kirjat.

Berger, Peter \& Thomas Luckmann ([1966]1991) The Social Construction of Reality. A Treatise in the Sociology of Knowledge. London: Penguin Books. (Ensijulkaisu 1966.)

Deetz, Stanley (1992) Disciplinary Power in the Modern Corporation. Teoksessa Alvesson, Mats ja Willmott, Hugh (toim.) Critical Management Studies. London: Sage Publications.

Deetz, Stanley (1998) Discursive Formations, Strategized Subordination and Self-surveillance. Teoksessa McKinlay, Alan and Starkey, Ken (toim.) Foucault, Management and Organization Theory: from Panopticon to Technologies of Self. London: Sage Publications.

Delamont, Sara (2004) Ethnography and Participant Observation. Teoksessa Seale, Clive; Gobo, Giampietro; Gubrium, Jaber F. ja Silverman, David (toim.) Qualitative Research Practice. London: Sage Publications.

Denzin, Norman K. \& Yvonna S. Lincoln (toim.) (2000) Handbook of Qualitative Research. Thousand Oaks: Sage Publications.

Dewey, John ([1927] 2006) Julkinen toiminta ja sen ongelmat. Tampere: Vastapaino. (Englannin kielinen alkuteos 1927, suomentanut Mika Renvall.)

Flick, Uwe (1998) An Introduction to Qualitative Research. London: Sage Publications Ltd.

Foucault, Michel (1970) The Order of Things. An Archaeology of Human Sciences. London: Tavistock.

Foucault, Michel (1972) The Archaeology of Knowledge. London: Tavistock.

Foucault, Michel (1977) Discipline and Punish: the Birth of the Prison. London: Penguin Books.

Foucault, Michel (1980) Power/Knowledge: Selected Interviews and Other Writings 1972-1977 (toim. C. Gordon). Hertfordshire: Harvester Wheatsheaf.

Foucault, Michel (1981) The History of Sexuality, Vol. 1. London: Allen Lane.

Foucault, Michel (1997) Essential Works of Foucault 1954-1984, volume 1; Ethics: Subjectivity and Truth (toim. P. Rabinow). New York: The New Press. 
Gergen, Kenneth. J* (1999) An Invitation to Social Construction. London: Sage Publications. Gervais, Marie-Claude (1999) Social Constructionism. The London School of Economics and Political Science, Department of Social Psychology. Julkaisematon.

Hakala, Salli (2001) Strategista julkisuutta. Kun raha saa vallan valtionhallinnon tiedotuksessa. Tiedotustutkimus 24:2, 4-17.

Hakala, Salli (2005b) Desk-tutkimus valtionhallinnon viestinnästä. Teoksessa Nieminen, Hannu; Hakala, Salli; Huhtala, Hannele; Tarkiainen, Johanna; Slätis, Thomas ja Åberg, Leif: VISA - valtionhallinnon viestinnän seuranta- ja arviointijärjestelmä. Osa II. Valtioneuvoston julkaisuja 4/2005. Helsinki: Valtioneuvoston kanslia.

Hakala, Salli (2006) "Kansalaisia varten" - kuinka valtionhallinnon viestintää voisi arvioida?

Tiedotustutkimus 29:3, 7-21.

Heckscher, Charles (1994) Defining the Post-Bureaucratic Type. Teoksessa Heckscher, Charles \& Donellon, Anne (toim.) The Post-Bureaucratic Organization. New Perspectives on Organizational Change. London: Sage.

Hodgson, Damian E. (2004) Project Work: The Legacy of Bureaucratic Control in the Post-Bureaucratic Organisation. Organization 11:1, 81-100.

Hosking, Dian Marie \& Sheila McNamee (2006) The Social Construction of Organization. Copenhagen: Copenhagen Business School Press.

Hosking, Dian Marie \& Ian E. Morley (1991) A Social Psychology of Organising. Hertfordshire, UK: Prentice Hall and Harvester Wheatsheaf.

Huhtala, Hannele (2004) The Emancipated Worker? A Foucauldian Study of Power, Subjectivity and Organising in the Information Age. Helsinki: Suomen Tiedeseura, Commentationes Scientiarum Socialicum 64.

Huhtala, Hannele (2005a) Viestinnän toimijoiden näkökulmia ministeriöiden viestintään. Teoksessa Nieminen, Hannu; Hakala, Salli; Huhtala, Hannele; Tarkiainen, Johanna; Slätis Thomas ja Åberg, Leif (2005) VISA - valtionhallinnon viestinnän seuranta- ja arviointijärjestelmä. Osa I, Valtioneuvoston julkaisuja 3/2005. Helsinki: Valtioneuvoston kanslia.

Huhtala, Hannele (2005b) Strategia II: Viestinnän toimijoiden näkökulmia ministeriöiden viestintään. Teoksessa Nieminen, Hannu; Hakala, Salli; Huhtala, Hannele; Tarkiainen, Johanna; Slätis Thomas ja Åberg, Leif (2005). VISA - valtionhallinnon viestinnän seurantaja arviointijärjestelmä. Osa II, Valtioneuvoston julkaisuja 3/2005. Helsinki: Valtioneuvoston kanslia.

Huhtala, Hannele \& Salli Hakala \& Aino Laakso \& Annette Falk (2005) Tiedonkulku ja viestintä Aasian hyökyaaltokatastrofissa. Helsinki: Valtioneuvoston kanslia.

Huhtala, Hannele (2006a) Organisaatiotutkimuksen nykysuuntauksia. Teoksessa Ahola, Kirsi; Kivistö, Sirkku ja Vartia, Maarit (toim.) Työterveyspsykologia. Helsinki: Työterveyslaitos.

Huhtala, Hannele (2006b) Max Weberin byrokratia ja kriisiviestintä. Tiedotustutkimus 29:3, 22-37.

Huhtala, Hannele \& Hakala, Salli (2007) Kriisi ja viestintä. Helsinki: Gaudeamus.

Humphreys, Patrick \& Dina Berkeley \& Sandra Jovchelovitch (1996) Organisational psychology and psychologists in organisations: focus on organisational transformation. Interamerican Journal of Psychology, 30:1, 27-42.

Humphreys, Patrick (1998) Discourses underpinning decision support. Teoksessa Berkeley, Dina; Brezillon, Patrick ja Rajkovic, Vladislav (toim.) Context-Sensitive Decision Support. London: Chapman and Hall.

Kreps, Gary L. (1986) Organizational Communication. Theory and Practice. New York: Longman.

Lasswell, Harold D. (1948) The Structure and Function of Communication in Society. Teoksessa Lyman Bryson (toim.), The Communication of Ideas. New York: Harper and Row.

Lumijärvi, Ismo \& Jani Kaarlejärvi (2000) Ministeriöt arviointitutkimuksen hyödyntäjinä. Tampereen yliopiston hallintotieteen laitos, hallintotiede 2000 A23.

Morgan, Gareth (1997) Images of Organizations. London: Sage.

Nieminen, Hannu $\&$ Salli Hakala \& Hannele Huhtala \& Johanna Tarkiainen $\&$ Thomas Slätis $\&$ Leif Åberg (2005a) VISA - valtionhallinnon viestinnän seuranta- ja arviointijärjestelmä. Osa I, Valtioneuvoston julkaisuja 3/2005. Helsinki: Valtioneuvoston kanslia.

Nieminen, Hannu \& Salli Hakala \& Hannele Huhtala \& Johanna Tarkiainen \& Thomas Slätis \& Leif Åberg (2005b) VISA - valtionhallinnon viestinnän seuranta- ja arviointijärjestelmä. Osa II, Valtioneuvoston julkaisuja 3/2005. Helsinki: Valtioneuvoston kanslia.

Tiedotustutkimus $2007: 3$ 
Rose, Nikolas ([1989] 1999) Governing the Soul: the Shaping of the Private Self. London: Free Association Books. (Ensijulkaisu 1989.)

Sims, David \& Steve Fineman \& Yannis Gabriel (1993) Organizing and Organizations. London: Sage.

Townley, Barbara (1994) Reframing Human Resources Management: Power, Ethics and the Subject at Work. London: Sage.

Townley, Barbara (1998) Beyond Good and Evil: Depth and Division in Management of Human Resources, teoksessa McKinlay, A. ja Starkey, K. (toim.) Foucault, Management and Organization Theory: from Panopticon to Technologies of Self. London: Sage Publications. s. 191-210.

Weber, Max ([1920]1947) The Theory of Social and Economic Organization. London: Routledge \& Kegan Paul. (Saksankielinen alkuteos 1920.)

Weber, Max ([1921] 1978) Economy and Society. An outline of Interpretative Sociology. (toim. Roth G. \& Wittich, C.) Berkley: University of California Press. (Saksankielinen alkuteos 1921.)

Weick, Karl E. (1995) Sensemaking in Organizations. London: Sage Publications.

Yin, Robert K. (1994) Case Study Research: Design and Methods (2nd ed.) Applied Social Research Methods Series, Volume 5. London: Sage.

\section{Virallislähteet}

VNK. Valtioneuvoston kanslia (2001) Informoi, neuvoo, keskustelee ja osallistuu. Valtionhallinnon viestintä 2000-luvulla. Työryhmän muistio. VNK:n julkaisusarja 2001/5. Helsinki: Valtioneuvoston kanslia.

VNK. Valtioneuvoston kanslia (2002) Valtionhallinnon viestintäsuositus. Helsinki: Valtioneuvoston kanslia. 